\title{
The Effect of Augmented Reality Use on Achievement, Misconception and Course Engagement*
}

\author{
Mustafa Sirakaya \\ Ahi Evran University, Turkey \\ Ebru Kilic Cakmak \\ Gazi University, Turkey
}

Submitted: 05.03.2018

Accepted: 12.06 .2018

Published: 16.07 .2018

\begin{abstract}
Augmented reality is defined as a technology in which real world and virtual objects are combined with a simultaneous interaction. The aim of this study is to determine the effect of augmented reality use on students' achievement, misconception and course engagement. A (matched) quasi-experimental research design with both pretest and posttest control groups was used in the study. The sample of the study consisted of 118 seventh grade students receiving education in six different classes. The students in the experimental group took their lessons with an augmented reality learning material, while the students in the control group continued using their traditional course materials. An achievement test, a misconception test and the student course engagement questionnaire were used as data collection tools. As a result of a 7-week implementation, this study found that augmented reality technology increased the achievement level of students and eliminated their misconceptions. However, the study also found that augmented reality technology did not affect the course engagement of students.
\end{abstract}

Keywords: Augmented reality; Achievement; Misconception; Course engagement; Secondary school students; Astronomy education

\section{Introduction}

The use of technology is recognized as an important part of education. It is recommended as a solution in enabling effective learning at schools (Seferoglu, 2009). Studies showed that the use of technology in education increases the achievement levels of students, offers a meaningful learning tool by attracting students' attention to course content, and makes the learning process active and effective (Sumadio \& Rambli, 2010). The rapid development of technology has resulted in materials used for educational purposes to be updated and renewed constantly. Interactive boards, simulation software, and virtual reality environments are now being used, in addition to chalkboards and experiments in laboratories.

Virtual reality is defined as a three-dimensional (3D) technology that provides interaction simultaneously with movements made by the user while in a virtual environment. The virtual

\footnotetext{
* This article was produced from the first author's doctoral thesis titled "Effects of augmented reality applications on students' achievement, misconceptions and course engagement" at Gazi University, Ankara, Turkey.
} 
environment is a setting created by the computer technology that is perceived as real by the users during the experience (Hartma \& Bertoline, 2005). Although virtual reality and virtual environments offer rich learning experiences, they also have some disadvantages. First of all, their complete virtuality poses an obstacle for learners to form a natural and physical interaction. In their study, Matcha and Rambli (2013) stated that the use of technology in education decreases the communication and interaction between and among students. They also stated that the use of tools that enable students to physically interact with each other can solve the above-mentioned problem. Moreover, the complete lack of reality in virtual environments is also a serious shortfall. It is thought that this may have negative effects on the cognitive development of individuals (Piaget, 1976; Vygotsky, Hanfmann \& Vakar, 2012). These disadvantages led researchers to discover new tools which can be utilized in educational environments. One of these recent tools is augmented reality (AR).

\section{Augmented Reality and Its Use in Education}

Augmented reality (AR) is defined as a technology in which real world and virtual objects are combined with a simultaneous interaction (Azuma, 1997). As understood from this definition, AR can be considered as a developed form or derivation of virtual reality (Azuma, 1997). However, it is stated that AR has two important advantages, compared to virtual reality. One of these advantages is that the users in AR can interact simultaneously with virtual objects in the real environment. The second one is that AR encourages students to participate actively in forming their own knowledge base and provides them with the opportunity for concrete interaction (Ibili, 2013).

Although AR has been used in other fields for a long time, it is observed that studies about its usability and potential have only recently begun to be conducted in educational settings (Akcayir \& Akcayir, 2017; Fleck, Hachet, \& Bastien, 2015; Ibáñez \& Delgado-Kloos, 2018; Vilkoniene, 2009; Wu, Lee, Chang, \& Liang, 2013).

As well as being easy to use, AR has succeeded in attracting attention in terms of its use in education, thanks to its pedagogical benefits. It is observed that AR tools are used by a broad range of participants, from pre-school students to post-graduate students and teachers in a wide range of fields, from literacy education to astronomy education. The AR studies conducted in different fields can be seen in Figure 1. Such an intensive use of AR in a short time provides insight about the potential that AR technology offers for educational environments. Studies have reported the advantages provided by the use of AR in educational environments (Figure 2). A study conducted by Schrier (2006) emphasized that AR has a potential to develop skills which are expected from today's learners, such as problem solving, group work, versatile assessment and understanding different perspectives. As seen in Figure 2 , the use of $A R$ in educational environments has many advantages. However, it can be stated that the most important advantage offered by $A R$ is to integrate the contributions made by virtual environments with the reality of the classroom. AR includes all these advantages in simulations and in the real environment in which we exist, which is superior to virtual reality. Therefore, it enables students to be involved actively in a natural and simultaneous interaction with the real environment and with virtual objects (De Ravé, Jiménez-Hornero, Ariza-Villaverde \&Taguas-Ruiz, 2016; Matcha \& Rambli, 2013; Sin \& Badioze Zaman, 2009; Zimmerman, Land \& Jung, 2016). It appears that AR can be used as an effective tool for students to reach their learning goals (Hsu, 2017). 


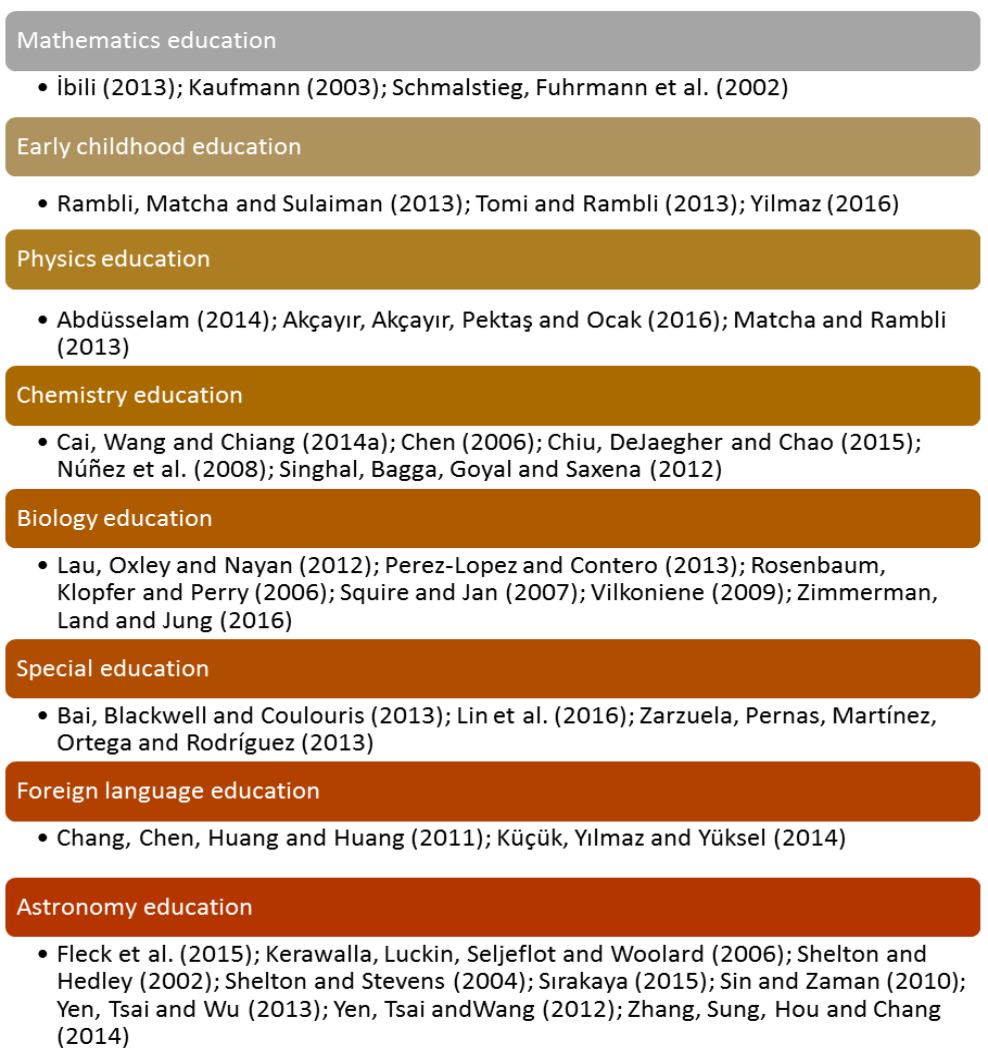

Figure 1. The AR Studies Conducted in Different Fields

\begin{tabular}{|c|c|}
\hline Advantages of AR & References \\
\hline $\begin{array}{l}\text { It increases students' } \\
\text { interest in learning. }\end{array}$ & $\begin{array}{l}\text { Cai, Chiang, Sun, Lin \& Lee (2017); Delello (2014); Perez-Lopez a } \\
\text { Contero (2013); Tomi and Rambli (2013); Yen et al. (2012) }\end{array}$ \\
\hline $\begin{array}{l}\text { It increases students' } \\
\text { motivation for learning. }\end{array}$ & $\begin{array}{l}\text { Delello (2014); Kerawalla et al. (2006); Küçük, Yılmaz, Baydaş and } \\
\text { Göktaş (2014); Sotiriou and Bogner (2008); Tomi and Rambli (2013); } \\
\text { Yen et al. (2012) }\end{array}$ \\
\hline It prov & $\begin{array}{l}\text { Rambli et al. (2013); Tomi and Rambli (2013); Yilmaz (2016); Zarzuela } \\
\text { et al. (2013) }\end{array}$ \\
\hline It facilitates | & $\begin{array}{l}\text { Akçayır et al. (2016); Cai et al. (2014); Delello (2014); Ivanova and } \\
\text { Ivanov (2011); Kaufmann (2003); Kerawalla et al. (2006); Rosenbaum } \\
\text { et al. (2006); Yen et al. (2013); Yoon, Anderson, Lin \& Elinich (2017) }\end{array}$ \\
\hline $\begin{array}{l}\text { It concretizes abstract } \\
\text { concepts. }\end{array}$ & Shelton and Hedley (2002); Shelton and Stevens (2004) \\
\hline $\begin{array}{l}\text { It develops spatial } \\
\text { ability. }\end{array}$ & $\begin{array}{l}\text { Bujak et al. (2013); Cheng and Tsai (2013); Medicherla, Chang and } \\
\text { Morreale (2010) }\end{array}$ \\
\hline $\begin{array}{l}\text { It develops } \\
\text { collaboration. }\end{array}$ & $\begin{array}{l}\text { Billinghurst, Kato and Poupyrev (2001); Schrier (2006); Squire and Jan } \\
\text { (2007); Yuen, Yaoyuneyong and Johnson (2011) }\end{array}$ \\
\hline It enriches interaction. & $\begin{array}{l}\text { Cai et al. (2014); Sin and Zaman (2010); Wojciechowski and Cellary } \\
\text { (2013); Wu et al. (2013); Zimmerman et al., (2016) }\end{array}$ \\
\hline $\begin{array}{l}\text { It overcomes } \\
\text { misconceptions. }\end{array}$ & $\begin{array}{l}\text { Fleck et al. (2015); Fleck and Simon (2013); Rosenbaum et al. (2006); } \\
\text { Shelton and Hedley (2002); Sirakaya (2015); Tian, Endo, Urata, Mouri } \\
\text { and Yasuda (2014) }\end{array}$ \\
\hline $\begin{array}{l}\text { It increases } \\
\text { engagement. }\end{array}$ & $\begin{array}{l}\text { Abdüsselam and Karal (2012); Bai et al. (2013); Cai, Chiang and Wang } \\
\text { (2013); Dunleavy, Dede and Mitchell (2009); Yusoff and Dahlan (2013) }\end{array}$ \\
\hline
\end{tabular}

Figure 2. Advantages Offered by the Use of AR 


\section{Problem Description and Research Questions}

AR technology provides an important visualization opportunity in educational environments. Three-dimensional lesson contents can be developed by using the AR technology. Threedimensional lesson contents provide students with the opportunity to examine objects with features such as location, angle, rotation, and turning (Shelton \& Hedley, 2002; Shelton \& Stevens, 2004). Thanks to AR, environments which cannot be created under real world conditions (Kerawalla et al., 2006; Shelton \& Hedley, 2002; Yuen et al., 2011) and dangerous experiments (Eursch, 2007; Wojciechowski \& Cellary, 2013) can be taught safely. These advantages make $A R$ an important tool for teaching abstract concepts. Science is one of the fields on which AR studies have concentrated because it includes numerous abstract concepts (Karal \& Abdusselam, 2015). Astronomy is one field of science that includes many abstract concepts. Being a major part of science education (Chen, Yang, Shen, \& Jeng, 2007), astronomy is a field that enables students to acquire the skill of thinking logically and accurately. Goncu (2013) stated that students receiving astronomy education can acquire information through comprehending it, not memorizing it because they can think multi-dimensionally. Moreover, learning abstract astronomy concepts accurately fosters the development of perception and comprehension skills, and paves the way for students to learn other abstract concepts more easily (Turk, Alemdar, \& Kalkan, 2012). However, misconceptions about astronomy subjects among students at different educational levels were observed in studies conducted on astronomy, which has these important features (Chiras, 2008; Cin, 2007; Ozturk \& Doganay, 2013; Parnafes, 2012).

One of the reasons why misconceptions develop about astronomy subjects is that learning materials appropriate to the cognitive abilities of middle-school students are not used. The ability to comprehend three-dimensional dynamic objects and appropriate cognitive abilities need to be developed in order to understand three-dimensional astronomical concepts (Aktamis \& Arici, 2013; Heywood, Parker, \& Rowlands, 2013). However, children in middle school learn about concrete matters more easily because the mental development of children progresses from concrete to abstract during this period. Even though the concepts such as space, dimension, and volume begin to develop in children during this period of concrete operations, their misconceptions remain; they can understand these concepts only during and after the period of abstract operations (Piaget, 1976). Therefore, learning tools which concretize abstract concepts are needed in order to enable students to understand threedimensional astronomy subjects (Sun, Lin, \& Wang, 2010).

Learning materials such as two-dimensional text, pictures, diagrams, video and animation remain inadequate in the education of three-dimensional astronomy subjects (Chen et al., 2007; Shelton \& Hedley, 2002). Textbooks used for this purpose also result in students having misconceptions (Yagbasan \& Gulcicek, 2003). Misconception, which is regarded as a serious obstacle for student achievement (Goncu \& Korur, 2012; Yagbasan \& Gulcicek, 2003), leads individuals to encounter serious problems in their educational, professional and daily lives. It is thought that the use of AR learning tools in astronomy education has a positive effect on student achievement, and in removing misconceptions due to its visualization property.

Student course engagement is necessary for a successful learning process. Course engagement is defined as the active participation of students in learning activities in their classes (Skinner, Kinderman, \& Furrer, 2009). Course engagement is regarded as an important indicator of student achievement (Handelsman, Briggs, Sullivan, \& Towler, 2005). It is believed that a low level of course engagement may have negative effects on course performance and the learning 
process (Wang, Bergin, \& Bergin, 2014). Therefore, researchers are conducting studies on methods and tools that may be able to increase the students' level of course engagement. AR is considered an effective tool that can be used for this purpose. Studies have reported that the use of AR technology in courses may have a positive effect on students' engagement (Abdusselam \& Karal, 2012; Dunleavy et al., 2009). Although studies reporting about AR technology and course engagement are available in the literature, (Cai, 2013; Delello, 2014; Yusoff \& Dahlan, 2013) which are in addition to the above-mentioned studies, the limited number of studies which test the effects of using AR on course engagement bears attention.

It is thought that visualization offered through the use of AR learning materials in the study of astronomy positively affects the achievement, and course engagement, and helps decrease the misconception of students, through the means of learning tools such as natural and physical interaction. Similar studies are needed to determine the effects of AR applications and create better environments. It is thought that the findings of these studies will offer an insight to both researchers and practitioners. Studies on the use of AR in astronomy studies were found to generally be conducted as screening studies for developing systems, or for determining the opinions of users. It is thought that this study will contribute to the literature because it is an experimental study addressing different variables in terms of the use of AR learning material in astronomy education.

This study, which focused on the effect of the use of AR on the achievement, misconception and course engagement of students, sought answers to the following questions:

- Does the use of augmented reality learning material make a significant difference regarding the achievements of students?

- Does the use of augmented reality learning material make a significant difference regarding the misconceptions of students?

- Does the use of augmented reality learning material make a significant difference regarding the course engagement of students?

\section{Method}

\section{Study Design}

A (matched) quasi-experimental research design with pretest and posttest control groups was employed in the study. The random assignment method was not used in this research design. In this design, attempts are made to match two of the available groups in terms of certain variables. The matched groups are assigned randomly to the operation groups (Buyukozturk, Kilic Cakmak, Akgun, Karadeniz, \& Demirel, 2008).

\section{Study Group}

The study group consisted of 118 seventh-grade students receiving education in six different classes. After the classes were matched based on the students' achievement levels in the Science and Technology course, overall achievement averages and according to teachers' opinions, the students were randomly assigned to experimental and control groups. Therefore, 
the experimental group consisted of 62 participants ( 31 females and 31 males) and the control group consisted of 56 participants ( 31 females, 25 males).

\section{Data Collection Tools}

An achievement test, a misconception test and the student course engagement questionnaire were used as data collection tools.

Achievement Test: An achievement test prepared by the researchers was used in the present study. First of all, a table of specifications to measure learning acquisitions within the field of the World and Universe unit was created. Based on this table of specifications, a multiple choice test consisting of 42 questions about each acquisition was prepared. In accordance with the opinions of four subject matter experts asked to ensure the content validity of this test, four questions were excluded from the test. The item analysis of the test was performed by administering it to 93 eighth grade students. A total of 11 items, the distinctiveness levels of which were below 0.30 , were excluded from the test, and the KR-20 reliability coefficient of the achievement test consisting of 27 items was calculated as 0.75 . The lowest and highest possible scores to be obtained from the test were 0 and 27 , respectively.

Misconception Test: A three-stage misconception test developed by Goncu (2013) was used in the present study. The questions in the first phase of the test include options which contain 1 correct understanding and 2 misconceptions in terms of the relevant acquisition. The second phase includes options which also contain the reasons for the options which were given in the first phase. The third phase includes the options, "I am sure" and "I am not sure", asking students to report whether they are sure or unsure about the answers that they had given. The four subject matter experts were asked for their opinions on the misconception test, which consisted of 15 questions with three phases. These experts decided that an additional phase should be added in which students could explain the reasons for their answers, using their own words. The item analysis of the test consisting of 4 phases was performed by administering it to 93 eighth grade students, and its KR-20 reliability coefficient was calculated as 0.79 .

Student Course Engagement Questionnaire: The Student Course Engagement Questionnaire was used in the present study. The questionnaire was developed by Handelsman et al. (2005) to determine the engagement of students in the Science and Technology course, and the validity and reliability study of its Turkish version was performed by Gurer (2013). The original questionnaire developed by Handelsman et al. (2005) consists of 23 items and 4 factors (skills engagement, emotional engagement, participation/interaction engagement and performance engagement). However, the adaptation study conducted by Gurer (2013) found as a result of analysis that the questionnaire consisted of 21 items and 3 factors (skills engagement, interaction/performance engagement and emotional engagement). The Cronbach's Alpha reliability coefficient of the questionnaire with a 5-point Likert type scale was calculated to be 0.91 .

\section{Learning Material}

A marker-based AR application, which was developed by Sirakaya (2015) and called "UzayAR", was used in the present study. The basic aim of UzayAR is to display the space environment, 
which teachers and students cannot display or concretize in their mind in three dimensional form due to various physical barriers in the real world. Two subject matter experts, two Science and Technology teachers and three technical field experts were asked to give their opinions regarding the development process of the UzayAR. The UzayAR application, which was developed using the Unity3D game engine, can be used in portable devices with the Android operating system. UzayAR includes 22 different AR activities. The screenshots of UzayAR are given in Figure 3.

\section{Pilot Testing and Original Implementation Process}

To eliminate the possible impact of newly introducing the application by enabling students to have more learning experience with AR learning materials, it was decided that the pilot testing of the study would be conducted with the students in the experimental group. For this purpose, an AR application called AtomAR was developed for the unit on the Structure and Properties of Substances by asking for the opinions of two Science and Technology teachers. At the end of the pilot testing, which lasted for 2 weeks, various precautions were taken to eliminate the cause of troubles which were observed during the testing.

The implementation process consisted of pilot testing ( 2 weeks), conducting pretests and posttests ( 1 week) and the original implementation ( 4 weeks), lasting for 7 weeks in total. The tablets, which were used by the groups that included two or three students during the implementation process, were provided by the researcher. The samples photos taken during the implementation can be seen in Figure 4.
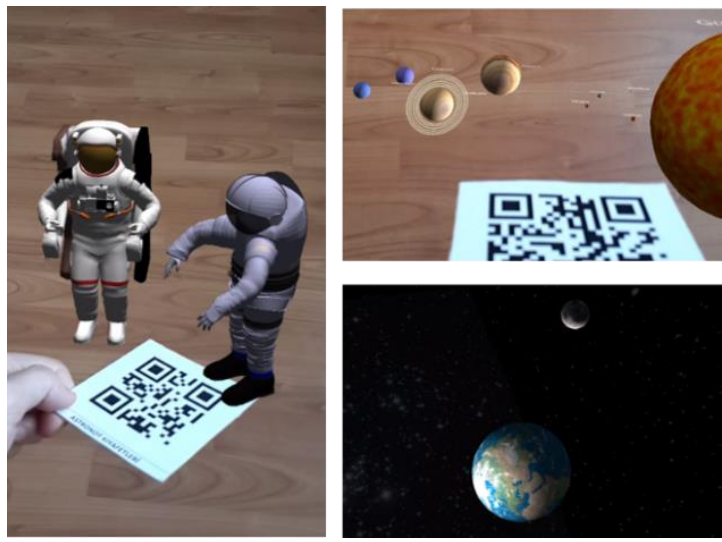

Figure 3. UzayAR Screenshots

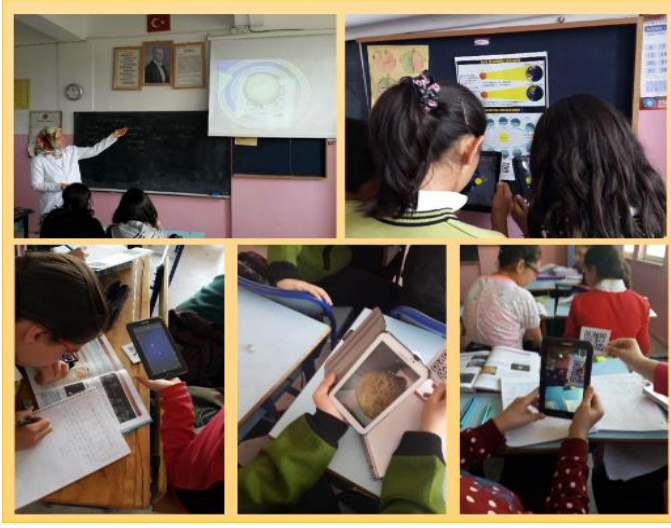

Figure 4. The Photos Taken During the Implementation

\section{Findings}

First of all, whether the required assumptions were ensured or not was checked to use the parametric tests for the data analysis. It was decided that the parametric tests could be performed because the sample size was larger than 30 (Roscoe, 1975 as cited in Buyukozturk et al., 2008) and the data showed normal distribution. The skewness-kurtosis coefficient within the range of \pm 2 (George \& Mallery, 2010) and the examination of the Q-Q plot graphs (Buyukozturk, 2007) were taken as a basis to test the normal distribution. 


\section{Findings about Student Achievement}

Independent sample single-factor analysis of variance (ANOVA) was performed to determine whether the pretest achievement levels of the students in the experimental and control groups showed significant differences from each other. These analyses showed that there was a significant difference between the pretest achievement mean scores in favor of the experimental group [F (1116) $=7,447, p>01]$.

A dependent samples t-test was performed on the achievement scores the students obtained from the pretest and posttest in order to test the effects of the AR learning materials on the achievement levels of students in the experimental group, and of the traditional course materials on those of students in the control group. The results of this test are shown in Table 1.

Table 1. The Comparison of Achievement Test Pretest and Posttest Scores of the Experimental and Control Groups

\begin{tabular}{|c|c|c|c|c|c|c|c|}
\hline Group & Test & $\mathrm{N}$ & $\overline{\mathrm{X}}$ & $S$ & sd & $\mathrm{t}$ & $p$ \\
\hline \multirow{2}{*}{ Experimental } & Pretest & 62 & 12.15 & 4.140 & \multirow{2}{*}{61} & \multirow{2}{*}{-7.341} & \multirow{2}{*}{.000} \\
\hline & Posttest & 62 & 15.94 & 4.875 & & & \\
\hline \multirow{2}{*}{ Control } & Pretest & 56 & 10.25 & 3.304 & \multirow{2}{*}{55} & \multirow{2}{*}{-1.780} & \multirow{2}{*}{.081} \\
\hline & Posttest & 56 & 11.36 & 4.622 & & & \\
\hline
\end{tabular}

The examination of Table 1 shows that the achievement scores of the students in the experimental group using the AR learning materials, and of the students in the control group using the traditional course materials increased. The analysis of this increase in the mean achievement scores by dependent samples t-test showed that there was a significant difference in favor of posttest in the experimental group $\left(t_{(61)}=-7.341, p<.01\right)$, while the increase which occurred in the control group was not statistically significant $\left(\mathrm{t}_{(55)}=-1.780, \mathrm{p}>.01\right)$. This finding can be interpreted as follows: Traditional course materials were inadequate in increasing students' achievement levels, whereas the AR learning materials had a positive effect on the students in terms of increasing their achievement levels.

Because the analyses conducted for the pretest scores of the experimental and control groups found that there was a significant difference in favor of the experimental group, single-factor analysis of covariance (ANCOVA) was performed to determine whether the change in the posttest scores, which were adjusted according to the pretest achievement scores, was significant or not. The students' posttest mean achievement scores which were adjusted according to their pretest achievement scores and the ANCOVA results are shown in Table 2.

Table 2. The ANCOVA Results of Posttest Achievement Scores Adjusted According to Pretest Achievement Scores by Groups

\begin{tabular}{|c|c|c|c|c|c|c|c|c|c|}
\hline Group & $\mathrm{N}$ & $\bar{x}$ & $\begin{array}{l}\text { Adjusted } \\
\text { Mean }\end{array}$ & $\begin{array}{l}\text { Source of } \\
\text { Variance }\end{array}$ & $\begin{array}{l}\text { Sum of } \\
\text { Squares }\end{array}$ & $\mathrm{sd}$ & $\begin{array}{l}\text { Mean } \\
\text { Square }\end{array}$ & $\mathrm{F}$ & $p$ \\
\hline \multirow{4}{*}{$\begin{array}{l}\text { Experimen } \\
\text { tal } \\
\text { Control }\end{array}$} & \multirow{4}{*}{$\begin{array}{l}62 \\
56\end{array}$} & \multirow{4}{*}{$\begin{array}{l}15.94 \\
11.36\end{array}$} & \multirow{4}{*}{$\begin{array}{l}15.37 \\
11.98\end{array}$} & $\begin{array}{l}\text { Pretest } \\
\text { (Reg) }\end{array}$ & 651.459 & 1 & 651.459 & 37.969 & .000 \\
\hline & & & & Group & 317.020 & 1 & 317.020 & 18.477 & .000 \\
\hline & & & & Error & 1973.140 & 115 & 17.158 & & \\
\hline & & & & Total & 25.592 & 118 & & & \\
\hline
\end{tabular}


According to the ANCOVA results as indicated in Table 2, there was a significant different between the experimental group using the AR learning material, and the control group using the traditional course materials, in terms of their posttest achievement scores, which were adjusted according to their pretest achievement scores $\left[\mathrm{F}_{(1-115)}=18.477, \mathrm{p}<.01\right)$. Considering all of these findings, it can be stated that the use of AR learning materials positively affected the students' achievement.

\section{Findings about Misconception}

According to pretest results, an ANOVA test was carried out to determine whether or not the number of misconceptions observed among the students in the experimental group and in the control group were significantly different from each other. The analysis showed that the difference between the pretest mean numbers of misconceptions was not significant $\left[F_{(1-116)}=2.884, p<.01\right]$. This finding can be interpreted as follows: the students in the experimental and control groups had misconceptions about the topic in similar numbers at the beginning of the process, and in this respect, they were equivalent to each other at the beginning of the process.

A dependent samples t-test was completed regarding the misconception numbers the students obtained from the pretest and posttest in order to test the effects of AR learning materials on the misconceptions of students in the experimental group, and of the traditional course materials on the misconceptions of those in the control group. The test results are shown in Table 3.

Table 3. The comparison of pretest and posttest misconception numbers of the experimental and control groups

\begin{tabular}{|c|c|c|c|c|c|c|c|}
\hline Group & Test & $\mathrm{N}$ & $\bar{x}$ & $\mathrm{~s}$ & $\mathrm{sd}$ & $\mathrm{t}$ & $\mathrm{p}$ \\
\hline \multirow{2}{*}{ Experimental } & Pretest & 62 & 6.18 & 2.62 & \multirow{2}{*}{61} & \multirow{2}{*}{8.658} & \multirow[b]{2}{*}{.000} \\
\hline & Posttest & 62 & 3.12 & 2.49 & & & \\
\hline \multirow{2}{*}{ Control } & Pretest & 56 & 5.39 & 2.37 & \multirow{2}{*}{55} & \multirow{2}{*}{-.280} & \multirow{2}{*}{.781} \\
\hline & Posttest & 56 & 5.51 & 3.21 & & & \\
\hline
\end{tabular}

According to Table 3, it was observed that the numbers of misconceptions in the experimental group using the AR learning material decreased. Also, the fact that the misconception numbers of students in the control group using the traditional course materials did not decrease draws attention. The analysis of this change in the numbers of misconception through examination of dependent samples from the t-test showed that there was a significant difference in favor of posttest in the experimental group $\left(t_{(61)}=8.658, p<.01\right)$; whereas, the change in the control group was not statistically significant $\left(t_{(55)}=-.280, p>.01\right)$. This finding can be interpreted as follows: The traditional course materials were inadequate in eliminating students' misconceptions, whereas the AR learning materials had a positive effect on reducing students' misconceptions.

An ANCOVA test was used to analyze the change in the mean misconception numbers of students before and after the implementation. The posttest mean misconception numbers of students in the groups, which were adjusted according to their pretest misconception means after the implementation, and the ANCOVA results are shown in Table 4. 
Table 4. The ANCOVA results of posttest misconception numbers adjusted according to pretest misconception means by the groups

\begin{tabular}{|c|c|c|c|c|c|c|c|c|c|}
\hline Group & $\mathrm{N}$ & $\bar{X}$ & $\begin{array}{l}\text { Adjusted } \\
\text { Mean }\end{array}$ & $\begin{array}{l}\text { Source of } \\
\text { Variance }\end{array}$ & $\begin{array}{l}\text { Sum of } \\
\text { Squares }\end{array}$ & sd & $\begin{array}{l}\text { Mean } \\
\text { Square }\end{array}$ & $F$ & $p$ \\
\hline \multirow{4}{*}{$\begin{array}{l}\text { Experimental } \\
\text { Control }\end{array}$} & \multirow{4}{*}{$\begin{array}{l}62 \\
56\end{array}$} & \multirow{4}{*}{$\begin{array}{l}3.13 \\
5.52\end{array}$} & \multirow{4}{*}{$\begin{array}{l}2.98 \\
5.69\end{array}$} & $\begin{array}{l}\text { Pretest } \\
\text { (Reg) }\end{array}$ & 121.252 & 1 & 121.252 & 16.847 & .000 \\
\hline & & & & Group & 210.681 & 1 & 210.681 & 29.272 & .000 \\
\hline & & & & Error & 827.698 & 115 & 7.197 & & \\
\hline & & & & Total & 1116.816 & 117 & & & \\
\hline
\end{tabular}

As seen in Table 4, there was a significant difference between the students in the experimental group using the AR learning materials and of those in the control group who used the traditional course materials, in terms of their posttest misconception numbers. These numbers were adjusted according to their pretest misconception means $\left[F_{(1-115)}=29.272, p<.01\right)$. Considering these findings, it can be stated that the use of AR learning materials in lessons had a positive effect on eliminating the students' misconceptions.

\section{Findings about Course Engagement}

An ANOVA test was conducted to determine whether the course engagement of students in the experimental and control groups showed a difference according to pretest results. The analyses showed that the difference between pretest course engagement total mean scores was not significant $\left[\mathrm{F}_{(1-116)}=.917, \mathrm{p}<.01\right]$. This finding can be interpreted as follows: The students in the experimental and control groups had similar characteristics in terms of course engagement at the beginning of the process and therefore, they were equivalent to each other.

A dependent samples t-test was carried out on the course engagement scores of students, which were obtained from the pretest and posttest, to analyze the effect of AR learning materials and the traditional course materials on the course engagement of students in the experimental group and in the control group, respectively. The test results are shown in Table 5.

Table 5. The Comparison of Pretest and Posttest Course Engagement Scores of Experimental and Control Groups

\begin{tabular}{|c|c|c|c|c|c|c|c|}
\hline Group & Test & $\mathrm{N}$ & $\overline{\mathrm{X}}$ & $\mathrm{S}$ & $\mathrm{sd}$ & $\mathrm{t}$ & $p$ \\
\hline \multirow{2}{*}{ Experimental } & Pretest & 62 & 83.67 & 14.37 & \multirow{2}{*}{61} & \multirow{2}{*}{$-1,732$} & \multirow{2}{*}{.088} \\
\hline & Posttest & 62 & 85.59 & 11.28 & & & \\
\hline \multirow{2}{*}{ Control } & Pretest & 56 & 81.14 & 14.30 & \multirow{2}{*}{55} & \multirow{2}{*}{-.640} & \multirow{2}{*}{.525} \\
\hline & Posttest & 56 & 82.05 & 15.90 & & & \\
\hline
\end{tabular}

The examination of Table 5 shows that the course engagement scores of students in the experimental group using the AR learning materials and in the control group using the traditional course materials increased. The dependent samples t-test used to analyze this increase in terms of the experimental and control groups showed that this increase in both the experimental group ( $t$ (61) $=-1.732, p>.01)$ and the control group $\left(t_{(55)}=-.640, p>.01\right)$ was not statistically significant. This finding can be interpreted as follows: The AR learning materials and traditional course materials did not have any effect on the course engagement of students. 
An ANCOVA test was employed to analyze the change in the course engagement scores of students before and after the implementation. The posttest course engagement means which were adjusted according to the pretest course engagement means, and the ANCOVA results are shown in Table 6 .

Table 6. The ANCOVA Results of Posttest Course Engagement Means Adjusted According to Pretest Course Engagement Means by the Groups

\begin{tabular}{|c|c|c|c|c|c|c|c|c|c|}
\hline Group & $\mathrm{N}$ & $\bar{x}$ & $\begin{array}{l}\text { Adjusted } \\
\text { Mean }\end{array}$ & $\begin{array}{l}\text { Source of } \\
\text { Variance }\end{array}$ & $\begin{array}{l}\text { Sum of } \\
\text { Squares }\end{array}$ & $\mathrm{sd}$ & $\begin{array}{l}\text { Square } \\
\text { Mean }\end{array}$ & $F$ & $p$ \\
\hline \multirow{4}{*}{$\begin{array}{l}\text { Experimental } \\
\text { Control }\end{array}$} & \multirow{4}{*}{$\begin{array}{l}62 \\
56\end{array}$} & \multirow{4}{*}{$\begin{array}{l}85.58 \\
82.04\end{array}$} & \multirow{4}{*}{$\begin{array}{l}84.71 \\
83.01\end{array}$} & $\begin{array}{l}\text { Pretest } \\
\text { (Reg) }\end{array}$ & 12628.962 & 1 & 12628.96 & 160.876 & .000 \\
\hline & & & & Group & 84.288 & 1 & 84.2888 & 1.074 & .302 \\
\hline & & & & Error & 9027.649 & 115 & 78.501 & & \\
\hline & & & & Total & 22025.506 & 117 & & & \\
\hline
\end{tabular}

As seen in Table 6, there was not a significant difference between the students in the experimental group using AR learning materials and of those in the control group using the traditional course materials in terms of their posttest mean scores adjusted according to their pretest mean scores $[F(1-115)=1.074, p>.01)$. This finding can be interpreted as follows: The AR learning material did not have any effects on the course engagement of students.

\section{Discussion and Conclusion}

According to the achievement test findings, it was concluded that the students in the experimental group were more successful than those in the control group. This result indicates that the AR learning material can be effective in increasing the achievement level. Similarly, many studies in the literature found that AR-supported teaching increased the achievement levels of students (Abdusselam \& Karal, 2012; Fleck \& Simon, 2013; Shelton \& Hedley, 2002; Sin \& Zaman, 2010; Vilkoniene, 2009; Wang, 2017; Yen et al., 2013; Zhang et al., 2014). It is thought that the advantages provided by the use of AR technology in education caused this result. One of the abovementioned advantages is that AR technology increases students' interest and attention levels (Cai et al., 2017; Delello, 2014; PerezLopez \& Contero, 2013; Tomi \& Rambli, 2013; Yen et al., 2012). It is assumed that the sharp image and realistic quality of AR learning material is effective in drawing students' attention. Considering the fact that students have very little opportunities to make observations about astronomy subjects, it is obvious that realistic space images trigger students' curiosity. Fleck et al. (2015) and Rosenbaum et al. (2006) stated that AR applications can help achieve a sense of reality. Students who used AR learning material for the first time may be affected by the realistic space images that they encounter, and they may begin to show interest and direct their attention to the course.

It is assumed that attracting students' interest and attention to their course subjects is an important factor in helping them to be more successful in their studies. Another advantage of AR technology is that it enables students to play a more active role in their lessons, and ask more questions (Delello, 2014; Zhang et al., 2014). Playing an active role and asking their teachers more questions about the course may help students achieve a deeper knowledge of the subjects. It is certain that the most general advantage that AR technology has for educational environments is that it is an effective support tool which can be used in the learning and teaching process (Fleck \& Simon, 2013; Hsu, 2017; Matcha \& Rambli, 2013; Medicherla et al., 2010; Núñez et al., 2008; Perez-Lopez \& Contero, 2013; Sin \& Zaman, 2010; Tian et al., 2014). Thanks to its abovementioned advantages, AR technology can play a critical role that facilitates learning in educational environments. It can be stated that with all of these features, the use of AR technology in education removes serious obstacles to students' achievements. The fact that the students in the experimental group who used the AR learning 
material significantly showed higher levels of achievement can be considered the result of the important advantages gained through the use of the AR applications.

The present study found that the students in the experimental group had fewer misconceptions than those in the control group. This result indicates that the AR learning material can be effective in eliminating the misconceptions of students. There are a lot of studies available in the literature which support this result (Fleck et al., 2015; Fleck \& Simon, 2013; Kerawalla et al., 2006; Rosenbaum et al., 2006; Shelton \& Hedley, 2002; Tian et al., 2014; Yen et al., 2012). The astronomy subjects generally include abstract concepts. Therefore, astronomy is one of the science subjects which are difficult for students to understand and perceive at a conceptual level (Turk et al., 2012). In order to learn concepts of astronomy, students need to envisage features of celestial bodies, such as their comparative sizes, the ratio of distance between them, their spatial location, and their geometric shapes. However, it is impossible for most groups of learners to grasp these concepts because of the cognitive stages that students undergo (Cai et al., 2014; Fleck et al., 2015). Moreover, it is not possible for students to learn astronomy events by observing or making an intervention, and seeing the results. For these reasons, certain tools are needed to help students learn complex astronomy subjects (Chen et al., 2007; Shelton \& Hedley, 2002).

It is believed that AR learning material is an effective tool in teaching astronomy subjects which include complex spatial relationships. The examination of literature shows that AR applications which enable students to make direct observations (Kerawalla et al., 2006; Sin \& Badioze Zaman, 2009; Sin \& Zaman, 2010; Soga, Matsui, Takaseki, \& Tokoi, 2008; Tian, Endo, Urata, Mouri, \& Yasuda, 2013; Tian et al., 2014; Yen et al., 2013; Zhang et al., 2014), or interact with celestial bodies (Fleck et al., 2015; Fleck \& Simon, 2013; Fleck, Simon, \& Christian Bastien, 2014; Medicherla et al., 2010; Shelton \& Hedley, 2002; Shelton \& Stevens, 2004), were developed to aid children in learning astronomy subjects. It is known that AR technology provides visualization of subjects and concepts which are hard to understand, and makes them comprehensible (Bujak et al., 2013; Kaufmann \& Schmalstieg, 2003; Kerawalla et al., 2006; Shelton \& Hedley, 2002; Yoon et al., 2017). The reason why the misconceptions of students in the experimental group decreased significantly compared with the control group may be the result of the visualization provided by the AR learning material. In the present study, the students had a chance to examine the astronomy subjects, which they cannot directly observe, in a three-dimensional way and from different perspectives through the means of the AR learning material. Therefore, it can be stated that the students had a learning experience which they cannot have in real life. Observing how the astronomy subjects and events occur actually might prevent the formation of new misconceptions and overcome any current misconceptions.

The present study found that there was no difference between the students in the experimental and control groups in terms of their course engagement. This result shows that AR learning material did not have any effect on ensuring the course engagement of students. Furthermore, this result is not consistent with the results of studies reporting that the use of AR increases the course engagement level of students (Abdusselam \& Karal, 2012; Bai et al., 2013; Cai, 2013; Delello, 2014; Dunleavy et al., 2009; Yusoff \& Dahlan, 2013). Studies conducted by Cai (2013) and Yusoff and Dahlan (2013) state that attracting attention, which is a feature of AR, positively affects the course engagement of students. In their study, Yusoff and Dahlan (2013) emphasized that using mobile technologies alone may decrease the interaction between students and decrease their course engagement levels. They also stated that AR-supported mobile learning increases both the motivation and course engagement levels of students. Contrary to the abovementioned study, a study conducted by Kerawalla et al. (2006) found that the students who used AR technology were less engaged in the course compared with the students being educated with conventional methods. The students preferred to use the AG application individually. AR technology enables students to learn at their own pace and manner, and supports individualized learning (Bujak et al., 2013). Moreover, it is also generally known that using 
technological tools in educational environments decreases the communication and interaction between and among students (Matcha \& Rambli, 2013). The fact that AR learning material did not have any effect on the course engagement of students may result from these factors.

The present study determined the effect of using AR on the achievement, misconception and course engagement of students. The study results showed that AR made positive contributions to the achievement of students, and in reducing the misconceptions of students; however, it did not affect their course engagement. With reference to this result, it can be stated that AR technology is an effective tool, which can be used in the education of middle school students. Considering the cognitive stages that these students undergo, AR technology may be preferred in teaching, particularly teaching abstract concepts. However, future studies to test the effect of AR on different sample levels can be made at different sampling levels. The misconceptions and course engagement levels of learners in the study were determined by tests and scales. Instead, studies can be conducted using data collection tools (open-ended questions, drawing, observation, interview, etc.) where richer data can be collected. In future studies, the effect of AR on different variables such as memory, cognitive load, and permanence can be tested.

\section{References}

Abdusselam, M. S. \& Karal, H. (2012). The effect of mixed reality environments on the students' academic achievement in physics education: 11th grade magnetism topic example. Journal of Research in Education and Teaching, 1(4), 170-181.

Akcayir, M., Akcayir, G., Pektas, H. M., \& Ocak, M. A. (2016). Augmented reality in science laboratories: The effects of augmented reality on university students' laboratory skills and attitudes toward science laboratories. Computers in Human Behavior, 57, 334-342.

Akcayir, M., Akcayir, G. (2017). Advantages and challenges associated with augmented reality for education: A systematic review of the literature. Educational Research Review, 20, 1-11.

Aktamis, H. \& Arici, V. A. (2013). The effects of using virtual reality software in teaching astronomy subjects on academic achievement and retention. Mersin University Faculty of Education Journal, 9(2), 58-70.

Azuma, R. (1997). A survey of augmented reality. Presence: Teleoperators and Virtual Environments, 6(4), 355-385. http://doi.org/10.1.1.30.4999

Bai, Z., Blackwell, F., \& Coulouris, G. (2013). Through the looking glass: Pretend play for children with autism. IEEE International Symposium on Mixed and Augmented Reality (pp. 49-58). Adelaide, Australia. DOI: 10.1109/ISMAR.2013.6671763

Billinghurst, M., Kato, H., \& Poupyrev, I. (2001). The MagicBook - moving seamlessly between reality and virtuality. IEEE Computer Graphics and Applications, 21)3). DOI: 10.1109/38.920621

Bujak, K. R., Radu, I., Catrambone, R., MacIntyre, B., Zheng, R., \& Golubski, G. (2013). A psychological perspective on augmented reality in the mathematics classroom. Computers \& Education, 68, 536-544.

Buyukozturk, S. (2007). Sosyal bilimler icin veri analizi el kitabı. Ankara: PegemA.

Buyukozturk, S., Kilic Cakmak, E., Akgun, O., E., Karadeniz, ŞS., \& Demirel, F. (2008). Bilimsel arastirma yontemleri. Ankara: Pegem Akademi.

Cai, H. (2013). Using augmented reality as motivators for youth enviromental education: An American Harts's tongue fern conservation project (Unpublished master's thesis). State University of New York. 
Cai, S., Chiang, F.-K., \& Wang, X. (2013). Using the augmented reality 3D technique for a convex imaging experiment in a physics course. International Journal of Engineering Education, 29(4), 856-865.

Cai, S., Chiang, F. K., Sun, Y., Lin, C., \& Lee, J. J. (2017). Applications of augmented reality-based natural interactive learning in magnetic field instruction. Interactive Learning Environments, 25(6), 778-791.

Cai, S., Wang, X., \& Chiang, F.-K. (2014). A case study of augmented reality simulation system application in a chemistry course. Computers in Human Behavior, 37, 31-40. http://doi.org/http://dx.doi.org/10.1016/j.chb.2014.04.018

Chang, Y.-J., Chen, C.-H., Huang, W.-T., \& Huang, W.-S. (2011). Investigating students' perceived satisfaction, behavioral intention, and effectiveness of English learning using augmented reality. Multimedia and Expo (ICME), (pp. 1-6). Barcelona, Spain: IEEE.

Chen, C. H., Yang, J. C., Shen, S., \& Jeng, M. C. (2007). A desktop virtual reality earth motion system in astronomy education. Journal of Educational Technology \& Society, 10(3), 289-304.

Chen, Y.-C. (2006). A study of comparing the use of augmented reality and physical models in chemistry education. Proceedings of the 2006 ACM international conference on virtual reality continuum and its applications (pp. 369-372).

Cheng, K.-H. \& Tsai, C.-C. (2013). Affordances of augmented reality in science learning: Suggestions for future research. Journal of Science Education and Technology, 22(4), 449-462.

Chiras, A. (2008). Day/Night Cycle: Mental models of primary school children. Science Education International, 19(1), 65-83.

Chiu, J. L., DeJaegher, C. J., \& Chao, J. (2015). The effects of augmented virtual science laboratories on middle school students' understanding of gas properties. Computers \& Education, 85, 5973.

Cin, M. (2007). Alternative views of the solar system among Turkish students. International Review of Education, 53(1), 39-53.

De Ravé, E. G., Jiménez-Hornero, F. J., Ariza-Villaverde, A. B., \& Taguas-Ruiz, J. (2016). DiedricAR: a mobile augmented reality system designed for the ubiquitous descriptive geometry learning. Multimedia Tools and Applications, 75(16), 9641-9663.

Delello, J. A. (2014). Insights from pre-service teachers using science-based augmented reality. Journal of Computers in Education, 1(4), 295-311.

Dunleavy, M., Dede, C., \& Mitchell, R. (2009). Affordances and limitations of immersive participatory augmented reality simulations for teaching and learning. Journal of Science Education and Technology, 18(1), 7-22.

Eursch, A. (2007). Increased safety for manual tasks in the field of nuclear science using the technology of augmented reality. 2007 IEEE Nuclear Science Symposium Conference Record (Vol. 3, pp. 2053-2059). IEEE.

Fleck, S. \& Simon, G. (2013). An augmented reality environment for astronomy learning in elementary Grades: an exploratory study. 25. Conference Francophone sur I'Interaction Homme-Machine, IHM'13. Bordeaux, France: ACM.

Fleck, S., Hachet, M., \& Bastien, C. (2015). Marker-based augmented reality: Instructional-design to improve children interactions with astronomical concepts. International Conference on Interaction Design and Children. Medford, MA: ACM. http://dx.doi.org/10.1145/2771839. 2771842 
Fleck, S., Simon, G., \& Christian Bastien, J. M. (2014). AIBLE: An inquiry-based augmented reality environment for teaching astronomical phenomena. 2014 IEEE International Symposium on Mixed and Augmented Reality - Media, Art, Social Science, Humanities and Design (IMSAR$M A S H^{\prime} D$ ) (pp. 65-66). IEEE.

George, D. \& Mallery, M. (2010). SPSS for windows step by step: A simple guide and reference. Boston: Pearson.

Goncu, O. (2013). Determining of astronomical misconception in fifth and seventh grade students (Unpublished master's thesis). Mehmet Akif Ersoy University, Burdur, Turkey.

Goncu, O., \& Korur, F. (2012). Ilkogretim ogrencilerinin astronomi temelli unitelerdeki kavram yanilgilarinin uc asamali test ile tespit edilmesi. X. National Science \& Matmematis Education Conference. Retrieved on 4 March 2018 from http://kongre.nigde.edu.tr/xufbmek/dosyalar/ tam_metin/pdf/2536-01_06_2012-16_35_38.pdf

Gurer, M. D. (2013). Utilization of learning objects in social studies session: Achievement, attitude and engagement. (Unpublished doctoral dissertation). Middle East Technical University, Ankara, Turkey.

Handelsman, M. M., Briggs, W. L., Sullivan, N., \& Towler, A. (2005). A measure of college student course engagement. The Journal of Educational Research, 98(3), 184-192.

Hartma, N. W., \& Bertoline, G. R. (2005). Spatial abilities and virtual technologies: Examining the computer graphics learning environment. Ninth International Conference on Information Visualisation. London: IEEE.

Heywood, D., Parker, J., \& Rowlands, M. (2013). Exploring the visuospatial challenge of learning about day and night and the sun's path. Dience Education, 97(5), 772-796.

Hsu, T.C. (2017). Learning English with augmented reality: Do learning styles matter? Computers \& Education, 106, 137-149.

Ibáñez, M. B. \& Delgado-Kloos, C. (2018). Augmented reality for STEM learning: A systematic review. Computers \& Education, 123, 109-123.

Ivanova, M. \& Ivanov, G. (2011). Enhancement of learning and teaching in computer graphics through marker augmented reality technology. International Journal of New Computer Architectures and Their Applications (IJNCAA), 1(1), 176-184.

Ibili, E. (2013). Geometri dersi icin artirilmis gerceklik materyallerinin gelistirilmesi, uygulanmasi ve etkisinin değerlendirilmesi (Unpublished doctoral dissertation). Gazi University, Ankara, Turkey.

Karal, H., \& Abdusselam, M. S. (2015). Artirilmis gerceklik. In B. Akkoyunlu, A. Isman, \& F. Odabaşı (Eds.), Eğitim Teknolojileri Okumaları (pp. 149-176). Ankara: TOJET.

Kaufmann, H. (2003). Collaborative augmented reality in education. Institute of Software Technology and Interactive Systems, Vienna University of Technology.

Kaufmann, H. \& Schmalstieg, D. (2003). Mathematics and geometry education with collaborative augmented reality. Computers \& Graphics, 27(3), 339-345.

Kerawalla, L., Luckin, R., Seljeflot, S., \& Woolard, A. (2006). Making it real: exploring the potential of augmented reality for teaching primary school science. Virtual Reality, 10(3-4), 163-174.

Kucuk, S., Yilmaz, R. M., Baydas, O., \& Goktas, Y. (2014). Augmented reality applications attitude scale in secondary schools: Validity and reliability study. Education and Science, 39(176), 383392. 
Kucuk, S., Yilmaz, R., \& Yuksel, G. (2014). Augmented reality for learning English: Achievement, attitude and cognitive load levels of students. Education and Science, 39(176), 393-404.

Lau, N., Oxley, A., \& Nayan, M. Y. (2012). An augmented reality tool to aid understanding of protein loop configuration. Computer \& Information Science (ICCIS), 2012 International Conference on (Vol. 1, pp. 500-505).

Lin, C.-Y., Chai, H.-C., Wang, J., Chen, C.-J., Liu, Y.-H., Chen, C.-W., ... Huang, Y.-M. (2016). Augmented reality in educational activities for children with disabilities. Displays, 42, 51-54.

Matcha, W. \& Rambli, D. R. A. (2013). Exploratory study on collaborative interaction through the use of augmented reality in science learning. Procedia Computer Science, 25, 144-153.

Medicherla, P. S., Chang, G., \& Morreale, P. (2010). Visualization for increased understanding and learning using augmented reality. Proceedings of the International Conference on Multimedia Information Retrieval (pp. 441-444). New York, NY, USA: ACM. http://doi.org/10.1145/ 1743384.1743462

Núñez, M., Quirós, R., Núñez, I., Carda, J. B., Camahort, E., Mauri, J. L., ... others. (2008). Collaborative augmented reality for inorganic chemistry education. WSEAS International Conference. Proceedings-Mathematics and Computers in Science and Engineering. Heraklion, Greece: ACM Digital Library.

Ozturk, A., \& Doganay, A. (2013). Primary school 5th and 8th graders' understanding and mental models about the shape of the world and gravity. Educational Sciences: Theory \& Practice, 13(4), 2469-2476.

Parnafes, O. (2012). Developing Explanations and Developing Understanding: Students Explain the Phases of the Moon Using Visual Representations. Cognition and Instruction, 30(4), 359-403.

Perez-Lopez, D., \& Contero, M. (2013). Delivering educational multimedia contents through an augmented reality application: A case study on its impact on knowledge acquisition and retention. Turkish Online Journal of Educational Technology, 12(4), 19-28.

Piaget, J. (1976). Piaget's theory. Berlin Heidelberg: Springer.

Rambli, D. R. A., Matcha, W., \& Sulaiman, S. (2013). Fun learning with AR alphabet book for preschool children. Procedia Computer Science, 25, 211-219.

Rosenbaum, E., Klopfer, E., \& Perry, J. (2006). On location learning: Authentic applied science with networked augmented realities. Journal of Science Education and Technology, 16(1), 31-45.

Schmalstieg, D., Fuhrmann, A., Hesina, G., Szalavari, Z., Encarnaçao, L. M., Gervautz, M., \& Purgathofer, W. (2002). The studierstube augmented reality project. Presence: Teleoperators and Virtual Environments, 11(1), 33-54.

Schrier, K. (2006). Using augmented reality games to teach 21st century skills. ACM SIGGRAPH 2006 Educators program on - SIGGRAPH '06 (p. 15). Boston, MA: ACM Digital Library.

Seferoglu, S. S. (2009). Ilkogretim okullarinda teknoloji kullanimi ve yoneticilerin bakis aciları. Akademik Bilişim '09 (pp. 403-410). Şanlıurfa, Turkey.

Shelton, B. E. \& Hedley, N. R. (2002). Using augmented reality for teaching earth-sun relationships to undergraduate geography students: Augmented reality toolkit. The First IEEE International Workshop (pp. 8). Darmstadt, Germany.

Shelton, B. E. \& Stevens, R. (2004). Using coordination classes to interpret conceptual change in astronomical thinking. Proceedings of the 6 th international conference for the learning sciences. Mahweh, NJ: Lawrence Erlbaum \& Associates. 
Sirakaya, M. (2015). Effects of augmented reality applications on students' achievement, misconceptions and course engagement (Unpublished doctoral dissertation). Gazi University, Ankara, Turkey.

Sin, A. K. \& Badioze Zaman, H. (2009). Tangible interaction in learning astronomy through augmented reality book-based educational tool. Lecture notes in computer science (including subseries lecture notes in artificial intelligence and lecture notes in bioinformatics) (Vol. 5857, pp. 302313). Berlin-Heidelberg: Springer.

Sin, A. K., \& Zaman, H. B. (2010). Live Solar System (LSS): Evaluation of an Augmented Reality bookbased educational tool. 2010 International Symposium on Information Technology (Vol. 1, pp. 1-6). IEEE.

Singhal, S., Bagga, S., Goyal, P., \& Saxena, V. (2012). Augmented chemistry: Interactive education system. International Journal of Computer Applications, 49(15), 1-5.

Skinner, E. A., Kinderman, T. A., \& Furrer, C. J. (2009). A motivational perspective on engagement and disaffection: Conceptualization and assessment of children's behavioral and emotional participation in academic activities in the classroom. Educational and Psychological Measurement, (69), 493-525.

Soga, M., Matsui, K., Takaseki, K., \& Tokoi, K. (2008). Interactive learning environment for astronomy with finger pointing and augmented reality. 2008 Eighth IEEE International Conference on Advanced Learning Technologies (pp. 542-543). Santander, Cantabria, Spain.

Sotiriou, S. \& Bogner, F. X. (2008). Visualizing the Invisible: augmented reality as an innovative science education scheme. Journal of Computational and Theoretical Nanoscience, 1(1), 114122.

Squire, K. D. \& Jan, M. (2007). Mad city mystery: Developing scientific argumentation skills with a place-based augmented reality game on handheld computers. Journal of Science Education and Technology, 16(1), 5-29.

Sumadio, D. D. \& Rambli, D. R. A. (2010). Preliminary evaluation on user acceptance of the augmented reality use for education. Proceedings of Second International Conference on Computer Engineering and Applications (pp. 461-465). Retrieved on 4 March 2018 from https://ieeexplore.ieee.org/stamp/stamp.jsp?arnumber $=5445691$

Sun, K.-T., Lin, C.-L., \& Wang, S.-M. (2010). A 3-d virtual realıty model of the sun and the moon for elearnıng at elementary schools. International Journal of Science and Mathematics Education, $8(4), 689-710$.

Tian, K., Endo, M., Urata, M., Mouri, K., \& Yasuda, T. (2013). Ubiquitous augmented reality mobile learning system for supporting moon observation. The International Conference on Business and Information (pp. 223-242). Retrieved on 4 March 2018 from https://pdfs.semanticscholar. org/e44a/83db642f5398ea883146e9e8264ca8615092.pdf

Tian, K., Endo, M., Urata, M., Mouri, K., \& Yasuda, T. (2014). Multi-viewpoint smartphone AR-based learning system for astronomical observation. International Journal of Computer Theory and Engineering, 6(5), 396-400.

Tomi, A. \& Rambli, D. R. A. (2013). An interactive mobile augmented reality magical playbook: Learning number with the thirsty crow. Procedia Computer Science, 25, 123-130.

Turk, C., Alemdar, M., \& Kalkan, H. (2012). Ilkogretim ogrencilerinin mevsimler konusunu kavrama duzeylerinin saptanmasi. Journal of Educational and Instructional Studies in the World, 2(1), 62-67. 
Vilkoniene, M. (2009). Influence of augmented reality technology upon pupils' knowledge about human digestive system: The results of the experiment. Online Submission, 6(1), 36-43.

Vygotsky, L., Hanfmann, E., \& Vakar, G. (2012). Thought and language. Cambridge, MA: MIT.

Wang, Y.-H. (2017). Exploring the effectiveness of integrating augmented reality-based materials to support writing activities. Computers \& Education, 113, 162-176.

Wang, Z., Bergin, C., \& Bergin, D. A. (2014). Measuring engagement in fourth to twelfth grade classrooms: The classroom engagement inventory. School Psychology Quarterly, 29(4), 517-35.

Wojciechowski, R. \& Cellary, W. (2013). Evaluation of learners' attitude toward learning in ARIES augmented reality environments. Computers \& Education, 68, 570-585.

Wu, H.-K., Lee, S. W.-Y., Chang, H.-Y., \& Liang, J.-C. (2013). Current status, opportunities and challenges of augmented reality in education. Computers \& Education, 62, 41-49.

Yagbasan, R., \& Gulcicek, C. (2003). Describing the characteristics of misconceptions in science teaching. Pamukkale University Journal of Education 1(3), 102-120.

Yen, J. C., Tsai, C. H., \& Wang, J. Y. (2012). The effects of augmented reality on students' moon phases concept learning and their conceptual changes of misconception. 2012 International Conference on Business and Information. Sapporo, Japan.

Yen, J.-C., Tsai, C.-H., \& Wu, M. (2013). Augmented reality in the higher education: Students' science concept learning and academic achievement in astronomy. Procedia - Social and Behavioral Sciences, 103, 165-173.

Yilmaz, R. M. (2016). Educational magic toys developed with augmented reality technology for early childhood education. Computers in Human Behavior, 54, 240-248.

Yoon, S., Anderson, E., Lin, J., \& Elinich, K. (2017). How augmented reality enables conceptual understanding of challenging science content. Educational Technology \& Society, 20 (1), 156168.

Yuen, S., Yaoyuneyong, G., \& Johnson, E. (2011). Augmented reality: An overview and five directions for AR in education. Journal of Educational Technology Development and Exchange, 4(1), 119140.

Yusoff, Z. \& Dahlan, H. M. (2013). Mobile based learning: An integrated framework to support learning engagement through augmented reality environment. Research and Innovation in Information Systems (ICRIIS), (pp. 251-256). Kuala Lumpur, Malaysia: IEEE.

Zarzuela, M. M., Pernas, F. J. D., Martínez, L. B., Ortega, D. G., \& Rodríguez, M. A. (2013). Mobile serious game using augmented reality for supporting children's learning about animals. Procedia Computer Science, 25, 375-381.

Zhang, J., Sung, Y.-T., Hou, H.-T., \& Chang, K.-E. (2014). The development and evaluation of an augmented reality-based armillary sphere for astronomical observation instruction. Computers \& Education, 73, 178-188.

Zimmerman, H. T., Land, S. M., \& Jung, Y. J. (2016). Using augmented reality to support children's situational interest and science learning during context-sensitive informal mobile learning. In A. Peña-Ayala (Ed.), Mobile, ubiquitous, and pervasive learning: Fundaments, applications, and trends (pp. 101-119). Switzerland: Springer International.

Correspondence: Mustafa Sirakaya, Assistant Professor, Department of Computer Technologies, Vocational School of Technical Sciences, Ahi Evran University, Kirsehir, Turkey. 